\title{
Factors affecting the availability to radishes of cadmium added to soil
}

\author{
AntTI JAAKKOLA ${ }^{1}$ ) \\ Department of Agricultural Chemistry, University of Helsinki \\ MATti J. SirÉn
}

\begin{abstract}
In a five week period, the cadmium uptake of radishes in pot experiments made in the greenhouse was on average $7.8 \%$ of the cadmium mixed with the soil $(0.4$ $\mathrm{mg} \mathrm{Cd}$ per $400 \mathrm{ml}$ of soil). In a material consisting of samples from 25 plough layers the uptake varied from 1.4 to $11 \%$ and in a material of samples from the corresponding subsoils from 1.4 to $22.6 \%$. The increase in cadmium content $(\Delta \mathrm{c})$ of the radish tops, which increase was regarded here as describing best the availability of added cadmium, varied in the plough layer material from 2.2 to $27.1 \mathrm{mg} / \mathrm{kg}$ and in the subsoil material from 4.3 to $94.9 \mathrm{mg} / \mathrm{kg} \mathrm{Cd}$ on a dry matter basis. The increment $\Delta \mathrm{c}$ was related to the amount of organic carbon $\left(\mathrm{x}_{1}\right)$ and to proportion of hydrogen $\left.\left(\mathrm{x}_{2}\right)\right)$ of total exchangeable cations according to the equation $\Delta \mathrm{c}=\mathrm{k} \cdot \frac{\mathrm{x}_{2} \mathrm{~b}_{2}}{\mathrm{x}_{1} \mathrm{~b}_{1}}$. In this equation $0<\mathrm{b}_{1}<1$ and $0<\mathrm{b}_{2} \leqq 1$. In the complete material of 50 soil samples, the coefficient of determination of the logarithmically transformed equation was $R^{2}=0.73$. The corresponding coefficient of determination in a material of plough layer samples $\left(\mathrm{R}^{2}=\right.$ 0.48) was imporoved when the increase in cadmium content of the radish tops grown in corresponding subsoil samples was included as an additional independent variable $\left(\mathrm{R}^{2}=0.59\right)$. This showed that some character other than any determined on the experimental soil was acting in the plough layer material.
\end{abstract}

According to present ideas, large amounts of cadmium in the human diet constitute a considerable risk to health (FrIBERG et al. 1974). Cadmium in the soil finds its way into the diet both directly in food plants and indirectly through fodder crops and animal products. The most important source of cadmium to plants is usually the soil, although considerable amounts may be deposited locally from the air (LAGERWERFF and SPECHT 1971). In areas fertilized with sewage from settlements or industry, the soil is in particular danger of contamination (LinNman et al. 1973). In addition, some fertilizers contain cadmium levels which may increase the danger (STENSTRöm and

1) Present address: Agricultural Research Centre, Department of Agricultural Chemistry and Physics, 01300 Vantaa 30. 
VAHTER 1974). The aim of this study was to clarify the effects of certain soil characteristics upon the availability of cadmium contaminating the soil.

\section{Material and methods}

The soil sample material consisted of $\mathbf{5 0}$ samples taken from 25 sites in various parts of South and East Finland. At each site samples were taken from the plough layer (topsoils) and below it to a depth of $40 \mathrm{~cm}$ (subsoils). The samples were allowed to reach an air-dry condition, and were ground to pass a $4 \mathrm{~mm}$ sieve.

A $400 \mathrm{ml}$ sample of each soil was put into a plastic pot, and an equal quantity weighed into another pot. The pots were fertilized with

N $\quad \begin{array}{lllllllllll} & \mathrm{P} & \mathrm{Mg} & \mathrm{Mn} & \mathrm{Cu} & \mathrm{Zn} & \mathrm{B} & \mathrm{Mo}\end{array}$

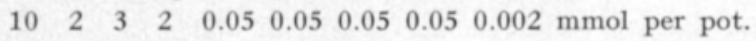

To one of each pair of pots $0.4 \mathrm{mg}$ of $\mathrm{Cd}$ were added as the nitrate. Water was added to the pots to give a soil water potential of $\mathrm{pF} 2.5$. This tension was measured with a pressure plate apparatus. In each pots, four radish plants (Raphanus sativus L. cv. Non Plus Ultra) were grown from seed to 36 days old in a greenhouse during April and May 1973. The water lost was made up at intervals by watering the pots to their original weight.

The aerial (tops) and underground (roots) parts of the radish plants were harvested separately. The roots were freed from the soil by washing with deionized water. Yields were weighed air-dry. Subsamples were used for a dry matter determination at $105^{\circ} \mathrm{C}$. After a wet combustion, the cadmium content was determined with a flameless atomic absorption spectrophotometer (Perkin Elmer). The cadmium uptakes were calculated from yields and their cadmium contents.

The following determinations were made on the experimental soils: $\mathrm{pH}$ in $0.01 \mathrm{M} \mathrm{CaCl}_{2}$ suspension, organic carbon, clay ( $<2 \mu \mathrm{m}$ fraction), iron extractable in acid ammonium oxalate at $\mathrm{pH} 3.3$, and also exchangeable hydrogen at $\mathrm{pH} 7$ and cation exchange capacity in soils saturated with $1 \mathrm{~N}$ ammonium acetate. The amounts of organic carbon, clay, soluble iron and of exchangeable hydrogen and cation exchange capacity were calculated for the soil in each pot by multiplying the weight of soil by the corresponding content.

The statistical treatment of the results was based mainly on correlation and regression analyses. Since the linear regression equation $y=a+b_{1} x_{1}$ $+b_{2} x_{2}+b_{3} x_{3}+\ldots+b_{k} x_{k}$ embodies the assumption that the variables $x_{1}, x_{2}, x_{3}$ etc. define additive parts of $y$, parts independent of one another, and since this assumption is presumably not valid, it was decided to test another type of model. The linear regression equation $\log y=\log \mathrm{a}^{\prime}+\mathrm{b}_{1}{ }^{\prime} \log \mathrm{x}_{1}+$ $\mathrm{b}_{2}{ }^{\prime} \log \mathrm{x}_{2}+\mathrm{b}_{3}{ }^{\prime} \log \mathrm{x}_{3}+\ldots \ldots \ldots+\mathrm{b}_{\mathrm{k}}{ }^{\prime} \log \mathrm{x}_{\mathrm{k}}$ incorporating the $\log -$ arithmically transformed variables was chosen for the test. When the independent variables $(x)$ influence one another, this model is more logical. The equation can be expressed in the form $y=a^{\prime} x_{1} b_{1}^{\prime} x_{2} b_{2}{ }^{\prime} x_{3}{ }^{b_{3}{ }^{\prime}} \ldots$ $\mathrm{x}_{\mathrm{k}} \mathrm{b}_{\mathbf{k}}{ }^{\prime}$, in which it is clear that the relative effect of each variable is assumed to be independent of the effect of other variables. 
Table 1. Amounts and variation of some characters determined on experimental soils.

\begin{tabular}{|c|c|c|c|c|c|c|}
\hline & \multicolumn{2}{|c|}{$\begin{array}{l}\text { Topsoils } \\
\mathrm{n}=25\end{array}$} & \multicolumn{2}{|c|}{$\begin{array}{l}\text { Subsoils } \\
\mathrm{n}=25\end{array}$} & \multicolumn{2}{|c|}{$\begin{array}{l}\text { Whole material } \\
\mathrm{n}=\mathbf{5 0}\end{array}$} \\
\hline & mean & $\begin{array}{l}\text { standard } \\
\text { deviation }\end{array}$ & $\overline{\text { mean }}$ & $\begin{array}{l}\text { standard } \\
\text { deviation }\end{array}$ & mean & $\begin{array}{r}\text { standard } \\
\text { deviation }\end{array}$ \\
\hline 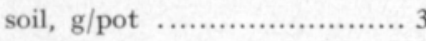 & 385 & 60 & 466 & 47 & 425 & 67 \\
\hline org. C, g/pot .................... & 17.7 & 8.7 & 4.0 & 2.9 & 10.9 & 9.4 \\
\hline clay $(<2 \mu \mathrm{m}), \mathrm{g} /$ pot $\ldots \ldots \ldots \ldots 1$ & 134 & 85 & 177 & 117 & 155 & 104 \\
\hline $\mathrm{CEC}, \mathrm{mval} /$ pot $\ldots \ldots \ldots \ldots \ldots \ldots \ldots$ & 129 & 48 & 113 & 53 & 121 & 51 \\
\hline $\begin{array}{l}\text { exch. } \mathrm{H}, \mathrm{mval} / \mathrm{pot} \\
\mathrm{Fe} \text {, soluble in ammonium }\end{array}$ & 72 & 19 & 57 & 19 & 65 & 20 \\
\hline oxalate, g/pot ................ & 3.62 & 1.99 & 3.73 & 2.30 & 3.67 & 2.13 \\
\hline $\mathrm{pH}_{\mathrm{CaCl}_{2}} \ldots \ldots \ldots \ldots \ldots \ldots \ldots \ldots$ & 4.9 & 0.46 & 5.1 & 0.55 & 5.0 & 0.51 \\
\hline
\end{tabular}

Table 2. Dry matter yield, its cadmium content and cadmium uptake of radish without added cadmium.

\begin{tabular}{|c|c|c|c|c|c|c|}
\hline & \multicolumn{2}{|c|}{$\begin{array}{l}\text { Topsoils } \\
\mathrm{n}=25\end{array}$} & \multicolumn{2}{|c|}{$\begin{array}{l}\text { Subsoils } \\
\mathrm{n}=25\end{array}$} & \multicolumn{2}{|c|}{$\begin{array}{l}\text { Whole material } \\
\mathrm{n}=50\end{array}$} \\
\hline & $\overline{\text { mean }}$ & $\begin{array}{l}\text { standard } \\
\text { deviation }\end{array}$ & mean & $\begin{array}{l}\text { standard } \\
\text { deviation }\end{array}$ & mean & $\begin{array}{r}\text { standard } \\
\text { deviation }\end{array}$ \\
\hline \multicolumn{7}{|l|}{ Tops } \\
\hline yield, g/pot .................. & . 1.37 & 0.22 & 0.99 & 0.26 & 1.18 & 0.31 \\
\hline Cd content, $\mu \mathrm{g} / \mathrm{g} . . . . . . . . .$. & 0.83 & 0.51 & 0.50 & 0.32 & 0.66 & 0.45 \\
\hline \multicolumn{7}{|l|}{ Roots } \\
\hline yield, $g /$ pot . .................. & . 1.74 & 0.45 & 1.48 & 0.55 & 1.61 & 0.51 \\
\hline Cd content, $\mu \mathrm{g} / \mathrm{g} . . . . . . . . .$. & 0.24 & 0.09 & 0.17 & 0.09 & 0.21 & 0.09 \\
\hline Cd uptake, $\mu \mathrm{g} /$ pot $\ldots \ldots \ldots \ldots \ldots$ & 1.50 & 0.75 & 0.72 & 0.46 & 1.11 & 0.73 \\
\hline
\end{tabular}

\section{Results and discussion}

On the basis of amounts present in the pots of soil (Table 1), the following average contents were obtained:

org. C, \% topsoils

clay, $\%$ of total weight ....................... 34.8

CEC, mval $/ 100 \mathrm{~g}$................................ $\quad 33.5$

$\begin{array}{lll}33.5 & 24.2 & 28.5\end{array}$

$\mathrm{Fe}, \mathrm{mg} / \mathrm{g}$, extractable in ammonium

oxalate, $\mathrm{pH} 3.3$.

subsoils

$\begin{array}{rr}0.9 & 2.6 \\ 38.0 & 36.5 \\ 24.2 & 28.5\end{array}$

8.0

The pots produced on average a dry matter yield of $2.8 \mathrm{~g}$ (Table 2), of which the proportion of roots was a little over half. Both the top and root yields of radishes grown on topsoils were on average significantly $(\mathrm{P}<0.05)$ greater than yields from subsoils. The native cadmium of the soil produced in the material a cadmium content of the tops at least three times higher on average than that of the roots. Deposition from the air was unlikely in this 
Table 3. Response of dry matter yield, its cadmium content and cadmium uptake of radish to cadmium application (400 $\mu \mathrm{g} / \mathrm{pot})$.

\begin{tabular}{|c|c|c|c|c|c|c|}
\hline & \multicolumn{2}{|l|}{$\begin{array}{l}\text { Topsoils } \\
\mathrm{n}=25\end{array}$} & \multicolumn{2}{|l|}{$\begin{array}{l}\text { Subsoils } \\
\mathrm{n}=25\end{array}$} & \multicolumn{2}{|c|}{$\begin{array}{l}\text { Whole material } \\
\mathrm{n}=50\end{array}$} \\
\hline & mean & $\begin{array}{r}\text { standard } \\
\text { deviation }\end{array}$ & mean & $\begin{array}{r}\text { standard } \\
\text { deviation }\end{array}$ & mean & $\begin{array}{r}\text { standard } \\
\text { deviation }\end{array}$ \\
\hline \multicolumn{7}{|l|}{ Tops } \\
\hline yield, $g /$ pot ............ & -0.05 & 0.24 & +0.01 & 0.16 & -0.02 & 0.20 \\
\hline Cd content, $\mu \mathrm{g} / \mathrm{g} \ldots .$. & +11.9 & 6.5 & +35.1 & 21.3 & +23.5 & 19.5 \\
\hline \multicolumn{7}{|l|}{ Roots } \\
\hline yield, $g /$ pot ............. & -0.04 & 0.45 & +0.07 & 0.31 & +0.02 & 0.38 \\
\hline Cd content, ug/g ...... & +3.1 & 1.6 & +7.5 & 6.6 & +5.3 & 5.2 \\
\hline Cd uptake, $\mu \mathrm{g} /$ pot...... & +20.2 & 10.3 & +41.9 & 20.9 & +31.1 & 19.6 \\
\hline
\end{tabular}

experiment. Of the total cadmium uptake (Table 2) in the whole material, an average of $70 \%$ was present in the aerial parts. Cadmium uptake was significantly greater from the topsoils than from the subsoils $(\mathrm{P}<0.001)$.

Addition of cadmium to the soils before sowing had no influence on the yield (Table 3). Differences in yield between the cadmium and no cadmium treatments were probably due to random influences. The variations of the differences were rather large and did not differ significantly from yield variations in the no cadmium treatments (cf. Table 2). Thus, there is some evidence that the latter variations were random, too, rather than dependent on differences between soils.

The increase in cadmium content of the tops was on average $\mathbf{4 - 5}$ times as large as the corresponding increase in the root content. In the whole material, radishes took up an average of $7.8 \%$ of the cadmium added. The range of variability was from 1.4 to $11.0 \%$ in the topsoils and from 1.4 to $22.6 \%$ in the subsoils. The increment in cadmium content of both tops and roots of radishes grown on subsoils was significantly greater than the increment for topsoils $(\mathrm{P}<0.01)$. Owing to this, also the uptake of applied cadmium was significantly greater from the subsoil than from the topsoil $(\mathrm{P}<0.001)$.

Of the quantities determined, cadmium uptake probably provides in theory the best measure of cadmium availability, whose assesment was aimed at. The uptake of applied cadmium was calculated according to the equation $\Delta y=y_{1}-y_{0} ; y_{i}=c_{1 i} a_{1 i}+c_{2 i} a_{2 i},(i=1,0)$, where

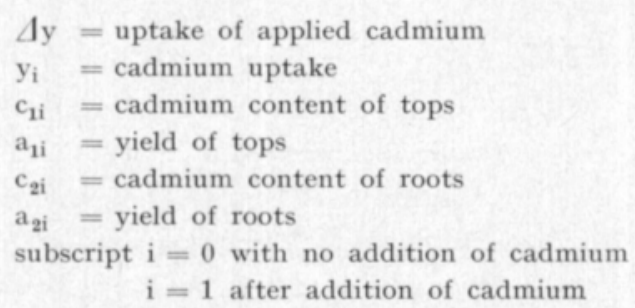


Table 4. Correlation coefficients between logarithms of difference in Cd content of tops and of certain soil properties.

\begin{tabular}{|c|c|c|c|}
\hline & $\begin{array}{l}\text { Topsoils } \\
\mathrm{n}=25\end{array}$ & $\begin{array}{l}\text { Subsoils } \\
\mathrm{n}=25\end{array}$ & $\begin{array}{l}\text { Whole material } \\
\mathrm{n}=50\end{array}$ \\
\hline organic $\mathrm{C} \ldots \ldots \ldots$ & $-0.58 * *$ & $-0.57 * *$ & $-0.78 * * *$ \\
\hline clay ................ & -0.32 & $-0.55^{* *}$ & -0.23 \\
\hline CEC ................ & $-0.63^{* *}$ & $-0.58 * *$ & $-0.58 * * *$ \\
\hline exch. $\mathrm{H}$........... & -0.36 & 0.03 & $-0.33^{*}$ \\
\hline exch. H/CEC .... & $0.44^{*}$ & $0.56^{* *}$ & $0.31^{*}$ \\
\hline $\left.\mathrm{pH}^{1}\right) \quad \ldots \ldots \ldots \ldots \ldots$ & -0.15 & -0.38 & -0.15 \\
\hline $\mathrm{Fe} \ldots \ldots \ldots \ldots \ldots \ldots$ & -0.32 & $-0.62 * *$ & $-0.38^{*}$ \\
\hline
\end{tabular}

1) untransformed values

It is apparent from the equation that all of the variation in yields is expressed in the calculated values of cadmium uptake. When this variation is large (cf. Tables 2 and 3) and presumably random, it seems likely that the use of the cadmium content as the independent variable instead of the calculated cadmium uptake would allow the attainment of a higher coefficient of determination and a more correct result in the regression analysis. Since the bulk of the cadmium in the plants is contained in the tops, variations were studied of the cadmium content of the tops in particular. The error caused by ignoring the roots is reduced by the fact that the cadmium contents of tops and roots showed a close, positive correlation with each other $\left(\mathrm{r}=0.956^{* * *}\right)$. The procedure used thus assumed that top yield is constant for the whole material, and that the top yield contains a constant proportion of the total plant cadmium. The fact that in almost all cases the cadmium content was better correlated than cadmium uptake with other soil characters tested argues in favour of the procedure. The cadmium contents of plants have been used for assessing the availability of soil cadmium by JoHn et al. (1972) and HAGHIRI (1974).

Correlations between the logarithms of the change in cadmium contents and of characters determined on the soils were rather poor (Table 4). In the whole material, organic carbon was rather well correlated with the dependent variable, but in each of the partial materials the correlation was poorer.

On the basis of pot experiments made with oats, HAGHIRI (1974) concluded that the depression in cadmium content of the tops associated with an increase in organic matter results solely from an increased cation exchange capacity. The results of the present study do not justify such an conclusion, since the cation exchange capacity accounted for significantly less $\left(r^{2}=0.33\right)$ of the variation in the cadmium content of the radish than did organic carbon $\left(\mathrm{r}^{2}=\right.$ 0.61 ). When organic carbon was taken into account in addition to the exchange capacity, the coefficient of determination was raised from $33 \%$ to $68 \%$ $(\mathrm{P}<0.001)$ in the whole material and from $34 \%$ to $44 \%(\mathrm{P}<0.05)$ for the subsoils. The increase from $39 \%$ to $48 \%$ for the topsoils was scarcely significant $(0.05<\mathrm{P}<0.10)$.

When the effects of organic carbon, clay, and of cation exchange capacity correlating well with these $\left(\mathrm{R}^{2}=0.80\right)$ were considered simultaneously (Table 
5), organic carbon was found to be the most important independent variable in the whole material and in the subsoil material. The coefficients of determination for the alternatives I and II in Tabel $\mathbf{5}$ did not differ significantly, but the effect of the proportion of exchangeable hydrogen (II) was more consistent than that of the cation echange capacity (I). The elimination of clay, whose correlation with the dependent variable is not significant, led to alternative III, to be considered in more detail below. The coefficient of determination for the whole material was $73 \%$, or greater than in the topsoil material $(48 \%)$ or the subsoil material $(59 \%)$.

The regression equations calculated according to alternative III in Table 5 express the following relationships:

$$
\begin{aligned}
& \text { topsoils } \quad \Delta \mathrm{c}=116.6 \cdot \frac{\mathrm{x}_{2}{ }^{0.83}}{\mathrm{x}_{1}{ }^{0.74}}\left(\mathrm{R}^{2}=0.48 \text { for logarithmic transformation }\right) \\
& \text { subsoils } \quad \Delta \mathrm{c}=89.2 \cdot \frac{\mathrm{x}_{2}{ }^{0.72}}{\mathrm{x}_{1}{ }^{0.61}}\left(\mathrm{R}^{2}=0.59-,-\right) \\
& \text { whole material } \Delta \mathrm{c}=99.0 \cdot \frac{\mathrm{x}_{2}{ }^{0.74}}{\mathrm{x}_{1}{ }^{0.69}}\left(\mathrm{R}^{2}=0.73-,-\right) \text {, in which equations } \\
& \Delta \mathrm{c}=\text { the difference, } \mathrm{mg} / \mathrm{kg} \text {, in cadmium contents between tops from cadmium and no } \\
& \text { cadmium treatments, } \\
& x_{1}=\text { amount of organic carbon, } g / \text { pot } \\
& \mathrm{x}_{2}=\text { proportfon oi hydrogen of exchangeable cations. }
\end{aligned}
$$

The exponentials (regression coefficients after logarithmic transformation) of all the equations given were significant. The high hydrogen proportion and the low amount of organic carbon thus represent a large increase in the cadmium content of the tops. The simplest explanation is that the increase in cadmium content is directly proportional to the proportion of exchangeable hydrogen, and inversely proportional to the amount of organic carbon. While this hypothesis regarding exchangeable hydrogen could not be disproved, both in the subsoil material and in the whole material the exponential of the amount of organic carbon was significantly smaller than unity. This indicates that a given relative increase in organic carbon corresponds on average to a smaller relative decrease in cadmium content response of radish tops.

JoHn et al. (1972) have also established that the cadmium content of radish tops depends upon the content of soil organic matter and soil acidity expressed as $\mathrm{pH}$ measured on a suspension of soil in salt solution. In their material, an additional independent variable was provided by a separate determination of the soil capacity for retaining cadmium from a solution. Part of the variation accounted for by this new variable would otherwise have been explained by organic matter and $\mathrm{pH}$. In the material of JoH et al. (1972), the iron soluble in dilute mineral acids raised the coefficient of determination considerably. In the material of the present study, however, iron extracted from the soil with acid ammonium oxalate at $\mathrm{pH} 3.3$ had no significance as an independent variable after the effects of organic carbon and exchangeable hydrogen had been eliminated. The present material is not strictly comparable with that of JoHs et al. (1972), as they determined iron by a different method. The iron content in their material averaged about $80 \mathrm{mg} / \mathrm{kg}$, in the present material $8600 \mathrm{mg} / \mathrm{kg}$. 
Table 5. Partial correlation coefficiants $(r)$ and coefficient of determination $\left(\mathrm{R}^{2}\right)$ between increase in cadmium content in radish tops (y) and organic carbon (1), clay fraction (2), cation exchange capacity (3) and hydrogen percentage of exchangeable cations (4) in soil (logarithmic transformation).

$\begin{array}{lll}\text { Topsoils } & \text { Subsoils } & \text { Whole material } \\ \mathrm{n}=25 & \mathrm{n}=25 & \mathrm{n}=50\end{array}$

I. Omitting effects of hydrogen percentage

\begin{tabular}{|c|c|c|c|c|}
\hline $\mathrm{r}_{\mathrm{y} 1.23}$ & ……....... & -0.34 & $-0.45^{*}$ & $-0.69^{* * *}$ \\
\hline $\mathrm{r}_{\mathrm{y} 2.13}$ & ........... & 0.00 & -0.26 & -0.11 \\
\hline$r_{y 3.12}$ & .......... & -0.35 & -0.01 & -0.20 \\
\hline$R^{2} y .123$ & & $0.48 * *$ & $0.48^{* *}$ & $0.68^{* * *}$ \\
\hline
\end{tabular}

II. Omitting effects of cation exchange capacity

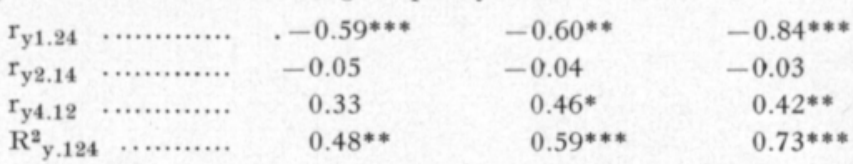

III. Omitting effects of clay fraction and cation exchange capacity

\begin{tabular}{|c|c|c|c|}
\hline$r_{y 1.4} \ldots \ldots \ldots \ldots \cdots \cdots$ & $-0.59^{* *}$ & $-0.63^{* *}$ & $-0.83^{* * *}$ \\
\hline$r_{y 4.1} \ldots \ldots \ldots \ldots \ldots$ & $0.47^{*}$ & $0.63^{* *}$ & $0.56 * * *$ \\
\hline$R^{2} y .14 \cdots \cdots$ & $0.48 * * *$ & $0.59 * * *$ & $0.73 * * *$ \\
\hline
\end{tabular}

The higher coefficient of determination in the whole material than in either of the component materials is due to differences in the partial correlation coefficients incorporating organic carbon. On the basis of its level of organic carbon, the material could be naturally divided into two components, whose mean responses of the cadmium content of the tops to added cadmium were different (cf. Table 3). This difference in means is not necessarily due solely to a difference in the amount of organic carbon between the component materials, but may also be caused by some character not determined here.

A larger proportion of the variation in increase of the cadmium content of radish tops could be accounted for in the subsoil material than in the topsoil material. It is possible that some character common to the plough layer and subsoil and not investigated here was influencing the results. For these reasons, an attempt was made to improve the coefficient of determination in the topsoil material by taking into account as an independent variable the increase in cadmium content of radishes grown in the corresponding subsoil sample. This measure increased significantly the coefficient of determination, from $48 \%$ to $57 \%$. The nature of the common character was quite unresolved. When the increase in cadmium content of radishes grown in subsoil was replaced by the proportion of hydrogen of subsoil exchangeable cations as an independent variable, the coefficient of determination did not fall significantly (to $55 \%$ ), but in any case this latter variable was not significant $(0.05<\mathrm{P}<0$. 10). It is conceivable that the proportion of exchangeable hydrogen in the subsoil characterizes soil acidity under constant conditions when organic carbon does not cause interference by its variations which are nevertheless apparent in the plough layer.

Acknowledgement. The authors wish to express their gratitude to Elintarviketuotannon edistämissäätiō (the Foundation for Promoting Foodstuff Production) for a grant which made it possible to carry out this study. 


\title{
REFERENCES
}

Friberg, L., Piscator, M., Nordberg, G. F. \& Kjellström, T. 1974. Cadmium in the Environment. 2nd Ed. 248 p. Cleveland.

Haghiri, F. 1974. Plant uptake of cadmium as influenced by cation exchange capacity, organic matter, zinc, and soil temperature. J. Environ. Quality 3:180-189.

John, M. K., VanLaerhoven, C. J. \& Снuah, H. H. 1972. Factors affecting plant uptake and phytotoxicity of cadmium added to soils. Environ. Sci \& Technol. 6: 1002-1009.

LAGerwerfF, J. V. \& SPEcht, A. W. 1971. Trace substances in environmental health. IV. Occurrence of environmental cadmium and zinc, and their uptake by plants. Proceedings of University of Missouri's annual conference on trace substances in environmental health. Colombia, Missouri 1971. p. 85-93.

Linnman, L., Andersson, A., Nilsson, O., Lind, B., Kjellström, T. \& Friberg, L. 1973. Cadmium uptake by wheat from sewage sludge used as a plant nutrient source. Arch. Environ. Health 27: 45-47.

Stenström, T. \& VAhter, M. 1974. Cadmium and lead in Swedish commercial fertilizers. Ambio 3: $91-92$.

MC received March 17, 1976.

\section{Selostus}

\section{Maahan lisätyn kadmiumin käyttökelpoisuus retiisille astiakokeessa}

\author{
ANTtI JАAKKоLA ${ }^{1}$ ) \\ Maanviljelyskemian laitos, Helsingin Yliopisto \\ MAtTi J. Sirén
}

Tutkimuksessa pyrittiin selvittämään eräiden maan ominaisuuksien vaikutus maahan lisätyn kadmiumin käyttökelpoisuuteen kasville. Tutkitut ominaisuudet olivat orgaaninen hiili, saves, kationinvaihtokapasiteetti, vedyn osuus vaihtuvista kationeista ja happameen ammoniumoksalaattiin liukeneva rauta.

Maanäyteaineiston muodostivat 25 paikasta etelä- ja itä-Suomesta otetut näytteet. Jokaisesta paikasta otettiin näyte kyntökerroksesta ja jankosta. Kasvihuoneessa järjestetyssä astiakokeessa määritettiin maihin sekoitetun kadmiumnitraatin $(0.4 \mathrm{mg} \mathrm{Cd} / 400 \mathrm{ml}$ maata) vaikutus viiden viikon ikään kasvatetun retiisin kadmiumpitoisuuteen ja kadmiuminottoon. Lisätystä kadmiumista retiisin laskettiin ottaneen yhteensa 1.4-22.6\%. Maanpäällisten osien kadmiumpitoisuuden nousun $(\Delta \mathrm{c})$ ja koeastian sisältämän orgaanisen hiilen määrän $\left(\mathrm{x}_{1}\right)$ sekä vaihtuvan vedyn osuuden $\left(\mathrm{x}_{2}\right)$ välillä todettiin yhteys $\Delta \mathrm{c}=\mathrm{k} \cdot \frac{\mathrm{x}_{2} \mathrm{~b}_{2}}{\mathrm{x}_{1} \mathrm{~b}_{1}} \cdot$ Lisäksi osoitettiin, että $0<\mathrm{b}_{1}<1$ ja $0<\mathrm{b}_{2} \leqq 1$. Koko 50 näytteen aineistossa, jossa $\Delta \mathrm{c}$ vaihteli $2.2-94.9$ $\mathrm{mg} / \mathrm{kg} \mathrm{Cd}$, tämän mallin logaritmimuunnos selitti $73 \%$ vaihtelusta. Kyntökerrosnäytteiden aineistossa, jossa selvitysaste oli huonompi (48\%) kuin jankkoaineistossa $(59 \%)$, vaihtelusta pystyttiin selittämäăn enemmän $(57 \%)$ ottamalla lisäksi selittävänä muuttujana huomioon retiisin kadmiumpitoisuuden nousu vastaavassa jankkoaineistossa. Tämän pääteltiin osoittavan, että kyntökerrokseen lisätyn kadmiumin käyttökelpoisuus riippui orgaanisen hiilen ja vaihtuvan vedyn osuuden lisäksi jostakin ominaisuudesta, jota ei ollut määritetty kyntökerrosnäytteistä ja joka oli korreloitunut jankossa vaikuttavien lisätyn kadmiumin käyttökelpoisuutta säätävien tekijöiden kanssa.

1) Nykyinen osoite: Maanviljelyskemian ja -fysiikan laitos, Maatalouden tutkimuskeskus, 01300 Vantaa 30 